\title{
MONITORING DAN EVALUASI PROGRAM BANTUAN OPERASIONAL SEKOLAH DI KOTA SALATIGA DENGAN MENGGUNAKAN ANALISIS KESENJANGAN TAHUN 2011/2012
}

\author{
Slameto \\ Program S1 Pendidikan Guru Sekolah Dasar (PGSD) \\ FKIP-Universitas Kristen Satya Wacana
}

\begin{abstract}
ABSTRAK
Monitoring dan evaluasi (monev) ini dilakukan untuk mengidentifikasi kesenjangan implementasi dan hasil Program Bantuan Operasional Sekolah (BOS) dengan mendasarkan hasil pengisian kuestioner dan Focus Group Discustion (FGP) dengan 24 orang stake-holder. Berdasarkan hasil analisis yang telah dilaksanakan diperoleh bahwa implementasi Program BOS di Salatiga ternyata terdapat kesenjangan yang bervariasi: tinggi, sedang dan rendah baik menyangkut proses implementasi maupun hasil program. Sesuai tujuan, ternyata dana BOS digunakan untuk mensubsidi seluruh siswa, mengurangi iuran yang dibebankan kepada orang tua siswa terutama yang miskin, diarahkan untuk membebaskan biaya pendidikan bagi siswa tidak mampu dengan tetap memperoleh layanan pendidikan yang lebih bermutu. Sesuai tujuan, hasil program BOS mencakup: BOS dapat menjadi akses untuk pengendalian pengelolaan dana pendidikan untuk menjamin penggunaan sumber daya finansial berlaku secara efisien, efektif, dan produktif; BOS memberi peluang bagi sekolah untuk membelanjakan pada kegiatan-kegiatan (baru) yang sebelumnya tidak terpenuhi dari sumber iuran bulanan. Terdapat kesenjangan yang tinggi dalam implementasi BOS, sehingga: ada keraguan apakah sekolah tetap dapat mempertahankan mutu pelayanan pendidikan apalagi harus menyelenggarakan sekolah gratis; apakah BOS digunakan secara transparan, dan para guru dilibatkan; dengan BOS yang diterima, sekolah belum dapat membebaskan seluruh biaya sekolah (hanya dapat membebaskan 40-70 persen dari biaya sekolah), sehingga masih harus melakukan penggalian dana dari sumber lain; terdapat sejumlah kebutuhan program sekolah yang strategis tetapi tidak dapat dibeayai oleh BOS; Dana BOS belum mampu mewujudkan sekolah gratis. Terdapat berbagai faktor, baik faktor internal sekolah maupun faktor eksternal; yang perlu mendapat perhatian dalam menentukan tindak lanjut, yaitu perlunya memodifikasi program terutama pada aras implementasi level sekolah dengan dukungan supra struktur birokrasinya.
\end{abstract}

Kata Kunci: Bantuan Operasional Sekolah (BOS), monitoring dan evaluasi program, analisis kesenjangan

\section{PENDAHULUAN}

UUD 1945 mengamanatkan kepada pemerintah untuk mencerdaskan kehidupan bangsa dan memajukan kesejahteraan umum. Oleh karena itu, pemerintah bertanggung jawab menyelenggarakan pendidikan dalam rangka memenuhi hak dasar setiap warga negara untuk memperoleh layanan pendidikan yang berkualitas. Pendidikan yang berkualitas dapat mengantarkan Indonesia menjadi bangsa yang modern, maju, makmur, dan sejahtera yang tercermin pada keunggulan dan kemampuan bersaing dengan bangsa-bangsa lain di dunia. Untuk itu, pemerintah telah menempatkan pendidikan sebagai salah satu prioritas utama dalam agenda pembangunan nasional. Pembangunan pendidikan diyakini akan memberi kontribusi signifikan pada upaya peningkatan kesejahteraan masyarakat dan 
menjadi landasan yang kuat dalam menghadapi era global yang sarat dengan persaingan antarbangsa yang berlangsung sangat ketat.

Upaya-upaya pemerintah dalam memberi layanan pendidikan yang baik bagi segenap anak bangsa, bertujuan untuk meningkatkan taraf pendidikan penduduk Indonesia, termasuk pelaksanaan Wajib Belajar Pendidikan Dasar Sembilan Tahun; Data Balitbang Depdiknas 2006 menunjukkan bahwa secara kuantitatif fasilitas layanan pendidikan sudah cukup baik. Meskipun demikian, kualitas layanan pendidikan masih terbatas karena dukungan fasilitas yang belum memadai, di samping kualitas guru yang masih rendah. Sehingga wajar jika jumlah siswa putus sekolah pada jenjang SD/MI, SMP/ MTs masih banyak. Pada tahun yang sama, cukup banyak lulusan SD/MI yang tidak dapat melanjutkan ke jenjang SMP/MTs. Masalah putus sekolah dan tidak dapat melanjutkan pendidikan terutama pada jenjang pendidikan dasar merupakan persoalan serius yang dapat mempengaruhi keberhasilan penuntasan program Wajib Belajar Pendidikan Dasar Sembilan Tahun.

Masalah ekonomi merupakan salah satu penyebab masih banyaknya anak usia sekolah yang berasal dari keluarga miskin yang tidak bisa bersekolah atau putus sekolah. Untuk menurunkan angka putus sekolah, Pemerintah menyediakan dana bantuan operasional sekolah (BOS), bantuan khusus sekolah (BKS), dan bantuan khusus murid (BKM) atau beasiswa. Berdasarkan survei Balitbang Depdiknas (2006), program BOS berhasil menurunkan secara signifikan angka putus sekolah dari 4,3 persen menjadi 1,5 persen, dan meningkatkan tingkat kehadiran siswa dari 95,5 persen menjadi 96,3 persen. Dengan adanya program BOS, sebanyak 70 persen SD/MI dan SMP/MTs telah membebaskan siswa dari segala jenis pungutan. Namun, disadari bahwa besaran dana BOS belum sepenuhnya dapat memenuhi kebutuhan operasional sekolah, terutama sekolah-sekolah yang berada di daerah perkotaan, sekolah swasta, dan sekolah unggulan.

Dalam upaya memperbaiki mutu pendidikan, layanan pendidikan terus ditingkatkan agar sesuai dengan standard nasional pendidikan dengan merujuk pada standard pelayanan minimal (SPM), yang sejauh ini belum sepenuhnya dapat dipenuhi. Meskipun Kebijakan desentralisasi dan otonomi pendidikan telah dilaksanakan, manajemen pelayanan pendidikan belum sepenuhnya efektif dan efisien. Oleh karena itu sasaran kebijakan dalam hal kualitas pendidikan, sangat perlu untuk terus ditingkatkan karena lembaga pendidikan belum sepenuhnya mampu memenuhi tuntutan masyarakat untuk melahirkan lulusan-lulusan yang berkompeten. Hal ini disebabkan oleh beberapa faktor antara lain: manajemen, kurikulum, dan sarana pendukung pembelajaran maupun administrasinya, guru dan evaluasi.

Ketertarikan untuk melakukan monitoring dan evaluasi pelaksanaan BOS dana BOS tersebut tidak diberikan langsung kepada siswa akan tetapi diterima dan dikelola oleh sekolah dan program BOS belum pernah dievaluasi (Abdul Kadir Karding. 2008), baik oleh lembaga sekolah maupun lembaga lain sehingga sampai dengan tahun 2008 belum diketahui seberapa manfaat dan cakupan, pemetaan BOS bagi siswa/siswi miskin atau kurang mampu. Oleh karena itu perlu untuk mengetahui tingkat efektivitas capaian sasaran program BOS khususnya di Kota Salatiga.

Rumusan masalah dalam monitoring dan evaluasi ini adalah bagaimana keberhasilan program BOS baik ditinjau dari segi proses implementasi maupun keberhasilannya berdasarkan persepsi stakeholder baik sebagai penerima layanan maupun pengelola program pada jenjang pendidikan dasar yaitu SD/MI dan SMP/MTs di Kota Salatiga.

Tujuan kegiatan monitoring dan evaluasi yang dilakukan dengan analisis kesenjangan ini adalah untuk menentukan proses perkembangan dan tingkat keberhasilan program BOS atas dasar perbandingan kondisi ideal dan kenyataan yang ada, beserta faktor pendukung dan penghambatnya. Pada akhirnya monev ini juga akan mengidentifikasi peluang/prospek program BOS dimasa yang akan datang. 
Monitoring dan evaluasi program ini diharapkan menghasilkan deskripsi perkembangan program BOS, keberhasilan, kendala serta prospeknya dimasa mendatang; yang hasilnya diharapkan bermanfaat untuk menjelaskan aksi program, masalah-masalah yang dihadapi, hasil/kinerja dan prospek masa depan dari program BOS yang pada akhirnya dapat digunakan sebagai saran untuk perbaikan implementasi kebijakan pendidikan.

\section{TINJAUAN PUSTAKA}

Bantuan Operasional Sekolah (BOS) merupakan kebijakan dalam bentuk paket subsidi pendidikan yang mulai diluncurkan pada Tahun 2005 yang bersumber dari PKPS BBM (Program Kompensasi Pengurangan Subsidi Bahan Bakar Minyak). Program BOS dilatar-belakangi oleh adanya kekhawatiran bahwa kenaikan harga BBM yang mengakibatkan turunnya daya beli masyarakat, juga akan berdampak negatif terhadap akses masyarakat miskin untuk mendapat Pendidikan Dasar (Wajardikdas) Sembilan Tahun. Sementara itu, UU No. 20 Tahun 2003 tentang Sistem Pendidikan Nasional, pasal 5, ayat (1) menyatakan bahwa "Setiap warga negara mempunyai hak yang sama untuk memperoleh pendidikan yang bermutu," dan pasal 11, ayat (1) menyatakan "Pemerintah dan Pemerintah Daerah wajib memberikan layanan dan kemudahan, serta menjamin terselenggaranya pendidikan yang bermutu bagi setiap warga negara tanpa diskriminasi." Dalam konteks ini, Program BOS dicetuskan sebagai upaya untuk meningkatkan akses masyarakat khususnya siswa dari keluarga miskin terhadap pendidikan yang berkualitas dalam rangka penuntasan wajib belajar sembilan tahun.

Penerima BOS adalah semua sekolah baik negeri maupun swasta di seluruh kabupaten/kota dan provinsi di Indonesia. Bagi sekolah kaya/mapan/yang mampu secara ekonomi, yang saat kebijakan BOS diterapkan, memiliki penerimaan lebih besar dari dana BOS tersebut, mempunyai hak untuk menolak BOS tersebut. Tujuan pemberian BOS kepada sekolah adalah sebagai bantuan kepada sekolah/ madrasah/salafiyah dalam rangka membebaskan iuran siswa, namun sekolah tetap dapat mempertahankan mutu pelayanan pendidikan kepada masyarakat. Bagi sekolah/madrasah/salafiyah yang selama ini (sebelum BOS diluncurkan) memungut iuran dari orang tua siswa lebih kecil dari BOS, maka sekolah/madrasah/salafiyah tersebut harus menyelenggarakan Sekolah Gratis dengan membebaskan segala bentuk iuran kepada seluruh siswa.

Sementara bagi sekolah/madrasah/salafiyah yang selama ini (sebelum BOS diluncurkan) memungut iuran dari orang tua siswa lebih besar dari BOS, maka sekolah/madrasah/salafiyah tersebut harus menyelenggarakan sekolah gratis terbatas, dengan ketentuan:

a. Bagi sekolah yang mempunyai siswa miskin, maka sekolah diwajibkan membebaskan semua iuran bagi seluruh siswa miskin yang ada di sekolah tersebut. Sisa dana BOS (bila masih ada) digunakan untuk mensubsidi siswa lain, sehingga iuran bulanan siswa lebih kecil dibandingkan sebelum menerima dana BOS.

b. Bagi sekolah yang tidak mempunyai siswa miskin, maka dana BOS digunakan untuk mensubsidi seluruh siswa, sehingga dapat mengurangi iuran yang dibebankan kepada orang tua siswa minimum senilai dana BOS yang diterima sekolah.

Meskipun tujuan utama program BOS adalah untuk pemerataan dan perluasan akses, program BOS juga merupakan program untuk peningkatan mutu, relevansi dan daya saing serta untuk tata kelola, akuntabilitas dan pencitraan publik. Melalui program BOS yang terkait dengan gerakan percepatan penuntasam Wajib Belajar 9 Tahun, maka setiap pelaksana program pendidikan harus memperhatikan hal-hal berikut:

a. BOS harus menjadi sarana penting untuk mempercepat penuntasanWajar Dikdas 9 Tahun. 
b. Melalui BOS tidak boleh ada siswa miskin putus sekolah karena tidak mampu membayar iuran/ pungutan yang dilakukan oleh sekolah/madrasah/ponpes.

c. Anak lulusan sekolah setingkat SD, harus diupayakan kelangsungan pendidikannya ke sekolah setingkat SMP. Tidak boleh ada tamatan SD/MI/setara tidak dapat melanjutkan ke SMP/MTs/ SMPLB dengan alasan mahalnya biaya masuk sekolah.

d. Kepala sekolah/madrasah/ponpes mencari dan mengajak siswa SD/MI/SDLB yang akan lulus dan berpotensi tidak melanjutkan sekolah untuk ditampung di SMP/MTs/SMPLB. Demikian juga bila teridentifikasi anak putus sekolah yang masih berminat melanjutkan agar diajak kembali ke bangku sekolah.

Program BOS dalam kerangka Manajemen Berbasis Sekolah dapat dipahami bahwa dalam program BOS, dana diterima oleh sekolah secara utuh, dan dikelola secara mandiri oleh sekolah dengan melibatkan dewan guru dan Komite Sekolah tanpa intervensi dari pihak lain. Dengan demikian program BOS sangat mendukung implementasi penerapan MBS, yang secara umum bertujuan untuk memberdayakan sekolah melalui pemberian kewenangan (otonomi), pemberian fleksibilitas yang lebih besar, untuk mengelola sumber daya sekolah, dan mendorong partisipasi warga sekolah dan masyarakat untuk meningkatkan mutu pendidikan di sekolah. Melalui program BOS, warga sekolah diharapkan dapat lebih mengembangkan sekolah dengan memperhatikan hal-hal berikut:

a. BOS harus menjadi sarana penting untuk meningkatkan pemberdayaan sekolah dalam rangka peningkatan akses, mutu dan manajemen sekolah.

b. Bagi siswa tidak mampu harus dibebaskan dari segala pungutan/gratis. Namun demikian, masyarakat dan orangtua siswa yang mampu diharapkan tetap berpartipasi dalam pengembangan sekolah.

c. Sekolah dapat melaksanakan semua kegiatan secara lebih professional, transparan, mandiri, kerjasama, dan dapat dipertanggung-jawabkan.

Organisasi pelaksana program BOS dipisah antara Departemen Pendidikan Nasional dan Departemen Agama. Di tingkat pusat, Provinsi dan kabupaten/kota terdapat Tim Manajemen BOS untuk masing-masing departemen dan tingkat pemerintahan. Sekolah yang menerima BOS diharuskan untuk mengikuti semua aturan yang ditetapkan oleh pengelola program, baik mengenai cara pengelolaan, penggunaan, pertanggungjawaban dana BOS yang telah diterima.

Saat dana BOS mulai dikucurkan (Juli 2005), data-base sekolah madrasah/salafiyah dan siswa penerima dana BOS masih belum akurat, sehingga menimbulkan kasus kelebihan dan keluhan selisih jumlah penerima BOS dibandingkan dengan jumlah siswa pada sebuah sekolah. Di sisi lain, timbul asumsi yang berkembang di kalangan aparat dan persepsi orang tua siswa bahwa dana BOS mampu menanggung seluruh beban biaya siswa bersekolah (sekolah gratis). Beberapa sekolah tertentu menganggap bahwa administrasi penggunaan dan pelaporan dana BOS malah merumitkan pekerjaan administrasi sekolah, sehingga ada diantara mereka memutuskan tidak bersedia menerima dana BOS. Hal ini menunjukkan bahwa konsep dan makna subsidi dana BOS yang diterima oleh aparat, sekolah, masyarakat, dan orang tua belum sepenuhnya dimengerti, akibat proses persiapan dan sosialisasi kebijakan yang dinilai lemah dan tidak intensif dilakukan.

Dampak BOS terhadap pembebasan iuran siswa keluarga miskin ternyata bahwa prinsip memberikan skim pembebasan kepada siswa miskin pada dasarnya sudah dijalankan oleh pihak sekolah, walaupun jumlahnya terbatas, masih belum meliputi jumlah aktual siswa miskin yang seharusnya memperoleh pembebasan iuran bulanan dan biaya transportasi, karena beberapa alasan dan pertimbangan. Secara umum, bahwa prinsip penurunan/ pengurangan iuran bulanan sudah dijalankan 
oleh pihak sekolah, walaupun jumlahnya bervariasi. Terdapat pihak sekolah/yayasan yang berpendapat bahwa dengan adanya BOS merupakan peluang bagi sekolah untuk membelanjakan pada kegiatankegiatan (baru) yang sebelumnya tidak terpenuhi dari sumber iuran bulanan.

Dana BOS dapat mengurangi beban orang tua untuk membayar pungutan lain di luar iuran bulanan, namun belum dapat mencukupi sepenuhnya biaya operasional sekolah baik pada jenjang SD/MI maupun SMPN/MTs. Sampai dengan tahun 2007, Manajer PKPS BOS mengakui bahwa jangkauan sosialisasi kebijakan BOS belum menyentuh semua lapisan stake-holders pendidikan (termasuk yayasan dan bendahara sekolah), sosialisasi belum dilakukan secara komprehensif untuk membangun pemahaman dalam hal penggunaan, pencatatan, dan pelaporan dana BOS. Persoalan lemahnya sosialiasi yang sering dikeluhkan dalam implementasi kebijakan publik (termasuk kebijakan BOS) sebenarnya tidak perlu terjadi, sebab hal yang diperlukan sebenarnya adalah sikap proaktif masyarakat untuk mencari dan memanfaatkan sumber informasi yang selengkap mungkin dari panduan/ pedoman atau produk informasi lainnya yang berkaitan dengan implementasi kebijakan publik (termasuk kebijakan BOS). Komite sekolah telah menunjukkan fungsi dan perannya karena telah dilibatkan dalam mekanisme pancairan dana BOS, dalam hal ini keterlibatan dan partisipasi aktif komite sekolah SMP/MTs/Salafiyah lebih baik dibandingkan dengan komite sekolah SD/MI/ Salafiyah.

\section{MODEL MONITORING DAN EVALUASI DENGAN ANALISIS KESENJANGAN}

Model menurut Silverman (2000) adalah keseluruhan kerangka kerja untuk melihat kenyataan. Model memberitahu kepada kita bagaimana realitas itu dan apa saja komponen dasar yang tercakup di dalamnya, dan bagaimana sifat dan kedudukan dari pengetahuan. Sedang Departemen P dan K, (1984) menyatakan bahwa model adalah pola (contoh, acuan, ragam) dari sesuatu yang akan dibuat atau dihasilkan. Definisi lain dari model adalah abstraksi dari sistem sebenarnya, dalam gambaran yang lebih sederhana serta mempunyai tingkat persentase yang bersifat menyeluruh, atau model adalah abstraksi dari realitas dengan hanya memusatkan perhatian pada beberapa sifat dari kehidupan sebenarnya (Simamarta, 1983).

Harre (Richey, 1986) memperkenalkan dua macam model, yaitu: micromorphs dan paramorphs. Model micromorphs adalah replika visual secara fisik atau replika visual dari realitas. Misalnya planetarium. Sedangkan paramorphs adalah model simbolik, yang secara khusus menggunakan deskripsi-deskripsi verbal. Misalnya analogi verbal. Model paramorphs secara umum dapat dikategorikan menjadi: (1) model konseptual, (2) model prosedural, dan (3) model matematik.

1. Model konseptual adalah model yang paling mungkin dikacaukan dengan teori, karena model konseptual adalah deskripsi verbal dan umum tentang gambaran realitas. Dalam model konseptual, komponen-komponen yang berkaitan dipresentasikan dan didefinisikan secara penuh. Model konseptual mungkin didukung oleh pengalaman dan data yang terbatas. Tidak ada pernyataan-pernyataan yang jelas tentang dalil atau proposisi-proposisi yang didukung oleh data yang banyak yang dikumpulkan secara sistematis.

2. Model prosedural adalah model yang menjelaskan bagaimana melakukan sebuah tugas. Sebagai contoh misalnya dalam desain instruksional, langkah-langkahnya biasanya didasarkan pada pengetahuan tentang apa yang berhasil menciptakan produk. Dalam studi ini dibatasi pada langkah-langkah melakukan gap analisis. Pengetahuan ini didasarkan pada pengalaman atau diturunkan dari teori atau model lain yang berkaitan.

3. Model matematik adalah persamaan-persamaan yang menjelaskan hubungan-hubungan antara berbagai macam komponen dari sebuah situasi. 
Provus (Suciptoardi, 2011) mendefinisikan evaluasi sebagai alat untuk membuat pertimbangan (judgement) atas kekurangan dan kelebihan suatu objek berdasarkan diantara standard dan kinerja. Menurut beliau evaluasi adalah untuk membangun dan affirmatif, tidak untuk meng-hakimi. Model Evaluasi Discrepancy/kesenjangan (Provus, dalam Suciptoardi, 2011) adalah suatu model evaluasi program yang menekankan pentingnya pemahaman sistem sebelum evaluasi. Model ini merupakan suatu prosedur problem-solving untuk mengidentifikasi kelemahan (termasuk dalam pemilihan standard) dan untuk mengambil tindakan korektif. Dengan model ini, proses evaluasi pada langkah-langkah dan isi kategori sebagai cara memfasilitasi perbandingan capaian program dengan standard, sementara pada waktu yang sama mengidentifikasi standard untuk digunakan untuk perbandingan di masa depan. Argumentasi Provus, bahwa semua program memiliki daur hidup (life cycle). Karena program terdiri atas langkah-langkah pengembangan, aktivitas evaluasi banyak diartikan adanya integrasi pada masingmasing komponennya.

Secara harafiah kata gap atau kesenjangan mengindikasikan adanya suatu perbedaan (disparity) antara satu hal dengan hal lainnya. Gap analysis sering digunakan di bidang manajemen dan menjadi salah satu alat yang digunakan untuk mengukur kualitas pelayanan (quality of services). Bahkan, pendekatan ini paling sering digunakan di Amerika Serikat untuk memonitor kualitas pelayanan. Gap analysis merupakan salah satu alat yang dapat digunakan untuk mengevaluasi kinerja Penyedia layanan. Hasil analisis tersebut dapat menjadi input yang berguna bagi perencanaan dan penentuan prioritas anggaran di masa yang akan datang. Selain itu, gap analysis atau analisis kesenjangan juga merupakan salah satu langkah yang sangat penting dalam tahapan perencanaan maupun tahapan evaluasi kinerja. Metode ini merupakan salah satu metode yang umum digunakan dalam pengelolaan manajemen internal suatu lembaga.

Analisis Gap (jarak) adalah suatu metode/alat membantu suatu lembaga membandingkan performansi aktual dengan performansi potensi. Operasionalnya dapat diungkapkan dengan dua pertanyaan berikut: "Dimana kita sekarang?" dan "Dimana kita inginkan?" Model yang dikembangkan oleh Parasuraman, Zeithaml dan Berry (1985) salah satu dari lima gap (kesenjangan), yaitu: kesenjangan antara standard pelayanan lembaga dan pelayanan yang diberikan; lembaga dalam hal ini adalah SD yang menerapkan MBS. Kesenjangan model ini menempatkan potensi kegagalan di pihak penyedia jasa, bukan di pihak konsumen. Dengan menggunakan gap analysis dapat diketahui semakin kecil kesenjangan tersebut, semakin baik kualitas pelayanan.

Gap akan bernilai $(+)$ positif bila nilai aktual lebih besar dari nilai target, sebaliknya bernilai (-) negatif apabila nilai target lebih besar dari nilai aktual. Apabila nilai target semakin besar dan nilai aktual semakin kecil maka akan diperoleh gap yang semakin melebar.

Tujuan analisis gap untuk mengidentifikasi gap antara alokasi optimis dan integrasi input, serta ketercapaian sekarang. Analisis gap membantu organisasi/ lembaga dalam mengungkapkan yang mana harus diperbaiki. Proses analisis gap mencakup penetapan, dokumentasi, dan sisi positif keragaman keinginan dan kapabilitas (sekarang). Tujuan dilakukan gap analisis adalah untuk melihat sejauh mana kesesuaian sistem yang sedang dijalankan dengan standard terkait yang harus dipenuhi.

Gap analysis bermanfaat untuk mengetahui kondisi terkini dan tindakan apa yang akan dilakukan di masa yang akan datang. Hubungan antara perusahaan sebagai supplier barang dan jasa dengan konsumen yang menggunakan barang dan jasa tersebut dapat membantu dalam memahami konsep gap analysis.

Secara singkat, gap analysis bermanfaat untuk: menilai seberapa besar kesenjangan antara kinerja aktual dengan suatu standard kinerja yang diharapkan; mengetahui peningkatan kinerja yang 
diperlukan untuk menutup kesenjangan tersebut, dan menjadi salah satu dasar pengambilan keputusan terkait prioritas waktu dan biaya yang dibutuhkan untuk memenuhi standard pelayanan yang telah ditetapkan.

Untuk terlaksananya suatu program, maka instansi menetapkan kegiatan-kegiatan yang merupakan penuangan dari program. Untuk menilai berhasil tidaknya suatu kegiatan maka penilaian dilakukan terhadap indikator kinerja kegiatan. Langkah gap analysis pada level indikator kinerja kegiatan sama dengan langkah yang dilakukan pada analisis indikator kinerja program. Analisis kesenjangan ini bertumpu pada evaluasi diri dan observasi lapangan termasuk sekolah untuk mendapatkan gambaran bagaimana kondisi dan kenyataan di lapangan. Peserta yang terlibat dalam pelaksanaan kegiatan analisis kesenjangan ini adalah 24 orang; mereka adalah Dosen PGSD dan perwakilan mahasiswa, Guru-guru dan Kepala Sekolah SD terpilih, Dinas Pendidikan Kota Salatiga, Dewan Pendidikan Kota Salatiga, Fasilitator MBS, dan Komite Sekolah SD/MI terkait.

Dalam melakukan gap analysis, terdapat beberapa langkah utama yang dilakukan seperti berikut ini.

1. Identifikasi komponen pelayanan yang akan dianalisis

Pelayanan yang akan dianalisis dapat berupa pelayanan secara umum ataupun pelayanan tertentu, misalnya pelayanan di bidang pendidikan atau kesehatan, atau pelayanan yang lebih spesifik, dalam hal ini adalah BOS.

2. Penentuan standard pelayanan

Standard pelayanan dapat berupa standard pelayanan formal maupun informal. Standard pelayanan formal adalah standard pelayanan yang tertulis, jelas, dan dikomunikasikan kepada seluruh staf pemberi layanan. Sementara itu, standard pelayanan informal adalah standard pelayanan tidak tertulis dan diasumsikan telah dimengerti oleh seluruh stake holder.

3. Penyebaran kuesioner atau wawancara terfokus

Isi kuesioner dan wawancara disesuaikan dengan desain gap analysis yang akan dilakukan. Pertanyaan kuesioner dan wawan-cara mencakup aspek dan dimensi yang akan diukur. Dimensi pelayanan misalnya adalah dimensi: dimensi keterlibatan, dimensi ketepatan, dimensi keterjaminan, dan dimensi empati. Untuk memudahkan pengukuran secara kuantitatif, maka setiap dimensi yang dinilai diberi skala atau skor. Hasil kuesioner yang menarik perlu dibahas melalui wawancara atau diskusi kelompok terfokus guna memperoleh data lebih lengkap sekaligus memvalidasinya.

4. Analisis Data

Dengan menggunakan statistik deskriptif dapat diketahui: rata-rata skor untuk setiap pasangan faktor yang sedang dikalkulasi kesenjangannya. Selain itu juga untuk perhitungan kesenjangan untuk masing-masing dimensi.

\section{Follow Up}

Dengan berdasarkan hasil analisis tersebut, kita dapat mengetahui kinerja pelayanan yang diberikannya. Selanjutnya lembaga yang bersangkutan dapat menyusun kebijakan yang diperlukan untuk menutupi kesenjangan tersebut.

Pengembangan model prosedural guna melakukan analisis kesenjangan dalam studi ini dilakukan kegiatan seperti berikut ini.

1. Identifikasi komponen program/pelayanan yang akan dianalisis

Program BOS yang akan dianalisis sesuai sesuai desain implementasi program terdiri dari 2 yaitu: komponen proses dan komponen hasil. 
2. Penentuan standard pelayanan

Dalam studi ini menggunakan standard yang dikembangkan dari berbagai sumber terkait dengan kebijakan BOS yang terangkum dalam 2 komponen yaitu proses (indikator a-g) dan hasil (indikator g-i) seperti berikut ini.

a. Tujuan pemberian BOS

b. Penggunaan Dana BOS untuk mensubsidi seluruh siswa,

c. Penggunaan BOS untuk membebaskan biaya pendidikan bagi siswa tidak mampu dan meringankan bagi siswa lain, agar mereka memperoleh layanan pendidikan dasar yang lebih bermutu sampai tamat

d. Pemerintah memberi jaminan/hak kepada sekolah untuk menolak BOS.

e. Bantuan kepada sekolah dalam rangka membebaskan iuran siswa,

f. Menyelenggarakan sekolah gratis

g. Pengawasan terhadap pelaksanaan yang transparan

h. Mempertahankan mutu pelayanan pendidikan

i. BOS dapat menjadi akses untuk pengendalian pengelolaan dana pendidikan oleh manajemen sekolah,

j. Untuk menjamin penggunaan sumber daya finansial berlaku secara efisien, efektif, dan produktif.

3. Penyebaran kuesioner atau wawancara terfokus

Isi kuesioner dan wawancara disesuaikan dengan desain gap analysis yang akan dilakukan. Pertanyaan kuesioner dan wawancara mencakup aspek dan dimensi yang akan diukur. Dimensi pelayanan misalnya adalah dimensi: fisik, dimensi keterlibatan, dimensi ketepatan, dimensi keterjaminan, dan dimensi empati. Untuk memudahkan pengukuran secara kuantitatif, maka setiap dimensi yang dinilai diberi skala atau skor. Pengisian kuesioner dilakukan pada sesi sebelum istirahat, sholat dan makan siang Selama peserta melakukan istirahat, dilakukan analisis hasil kuestioner secara cepat. Berdasarkan hasil kuestionaer, dipilih pokok-pokok yang menarik untuk dibahas dalam diskusi kelompok terfokus.

4. Analisis Data

Dengan menggunakan statistik deskriptif dapat diketahui: rata-rata skor untuk setiap pasangan faktor yang sedang dikalkulasi kesenjangannya. Selain itu juga untuk perhitungan kesenjangan untuk masing-masing dimensi beserta alasan/penjelasan berdasarkan hasil kuesioner yang dipertajam melalui FGD.

5. Follow Up

Dengan berdasarkan hasil analisis tersebut, kita dapat mengetahui kinerja pelayanan yang diberikannya. Selanjutnya lembaga yang bersangkutran diharapkan memperoleh balikan/hasil guna menyusun kebijakan yang diperlukan untuk menutupi kesenjangan tersebut.

\section{HASIL MONITORING DAN EVALUASI}

Berdasarkan analisis kesenjangan yang telah dilaksanakan atas implementasi program BOS tahun 2011/2012 diperoleh hasil monitoring dan evaluasi yang berdasarkan standard, ternyata terdapat kesenjangan yang bervariasi mulai dari kesenjangan yang tinggi, sedang dan rendah baik menyangkut proses implementasi maupun hasil program. Uraian yang dimaksud adalah seperti berikut ini.

1. Hasil Analisis Kesenjangan Proses Implementasi Program BOS

Implementasi BOS yang sesuai dengan yang seharusnya (kesenjangan rendah sampai sedang): 
a. Dana BOS digunakan untuk mensubsidi seluruh siswa, sehingga dapat mengurangi iuran yang dibebankan kepada orang tua siswa

b. BOS diarahkan untuk membebaskan biaya pendidikan bagi siswa tidak mampu dan meringankan bagi siswa lain, mereka memperoleh layanan pendidikan dasar yang lebih bermutu sampai tamat

c. Kendatipun kebijakan BOS ini berlaku secara nasional, pemerintah memberi jaminan/hak kepada sekolah untuk menolak BOS.

Terdapat kesenjangan yang tinggi dalam implementasi BOS, sehingga:

- Tujuan pemberian BOS kepada sekolah adalah sebagai bantuan kepada sekolah dalam rangka membebaskan iuran siswa, namun diragukan apakah sekolah tetap dapat mempertahankan mutu pelayanan pendidikan apalagi masih harus menyelenggarakan sekolah gratis

- Terdapat kesenjangan dalam pengawasan terhadap pelaksanaan yang dilakukan oleh Pemerintah dan masyarakat apakah BOS digunakan secara transparan, dan para guru dilibatkan

- Dengan alokasi dana BOS yang diterima, sekolah belum dapat membebaskan seluruh biaya sekolah (hanya dapat membebaskan 40 - 70 persen dari biaya sekolah), sehingga masih harus melakukan penggalian dana dari sumber lain.

2. Hasil Analisis Kesenjangan Atas Keberhasilan Program BOS

Hasil program BOS sesuai dengan tujuan yang seharusnya (kesenjangan rendah sampai sedang) mencakup:

a. Subsidi pemerintah (BOS) dapat menjadi akses untuk pengendalian pengelolaan dana pendidikan oleh manajemen sekolah, untuk menjamin penggunaan sumber daya finansial berlaku secara efisien, efektif, dan produktif.

b. Dengan adanya BOS memberi peluang bagi sekolah untuk membelanjakan pada kegiatankegiatan (baru) yang sebelumnya tidak terpenuhi dari sumber iuran bulanan

Adanya kesenjangan yang tinggi dalam pencapaian hasil dari program BOS, terkait dengan hal-hal berikut ini:

a. Terdapat sejumlah kebutuhan/program sekolah yang strategis tetapi tidak dapat dibiayai oleh BOS, karena tidak sesuai aturan

b. Dana BOS belum mampu menanggung seluruh beban biaya siswa bersekolah (sekolah gratis)

c. Sekalipun dana BOS dapat mengurangi beban orang tua untuk membayar pungutan lain di luar iuran bulanan, namun belum sepenuhnya dapat tercukupi.

\section{PEMBAHASAN}

Kesenjangan program adalah sebagai suatu keadaan antara yang diharapkan dalam rencana dengan yang dihasilkan dalam pelaksanaan program. Evaluasi kesenjangan dimaksudkan untuk mengetahui tingkat kesesuaian antara standard yang sudah ditentukan dalam program dengan penampilan aktual dari program tersebut. Standard adalah: kriteria yang telah dikembangkan dan ditetapkan dengan harapan hasil yang efektif. Penampilan adalah: sumber, prosedur, manajemen dan hasil nyata yang tampak ketika program dilaksanakan.

Penggunaan analisis kesenjangan sebagai model monev program, pada tahap pembandingan program, yaitu tahap membandingkan hasil yang telah dicapai dengan tujuan yang telah ditetapkan, telah dituliskan semua penemuan kesenjang-an untuk disajikan seperti di atas, agar 
para stakeholder terutama implementor dapat memutuskan kelanjutan dari program BOS. Kunci dari monitoring dan evaluasi ini adalah membandingkan penampilan dengan standard/tujuan yang telah ditetapkan.

Model monitoring dan evaluasi Program BOS dengan menggunakan analisis kesenjangan ini dapat menjadi salah satu alat yang digunakan untuk mengukur kualitas pelayanan/program; juga dapat digunakan untuk mengevaluasi kinerja pemerintah sebagai penyedia layanan. Analisis kesenjangan yang bertumpu pada kondisi dan kenyataan di SD/MI dan SMP/MTs penyelenggara BOS tahun 2011/2012, dengan menggunakan Standard BOS ini teruji sebagai model monitoring evaluasi yang cukup sederhana, memungkinkan untuk diterapkan dan digunakan secara luas karena mampu menghasilkan informasi yang relatif lengkap dari berbagai dimensi program (BOS).

Hasil monev ini ternyata tidak jauh berbeda dengan temuan Erwantosi (2010) yang menyatakan bahwa pengelolaan BOS SMP di Kota Padang belum efektif dalam meningkatkan akses dan mutu pendidikan pada sekolah menengah pertama. Pemberian prioritas yang memadai kepada siswa miskin belum tercapai. Penggunaan dana BOS sebagian besar hanya terserap untuk pembayaran honorarium guru dan pegawai. Lebih lanjut diungkapkan bahwa akuntabilitas dan transparansi dalam pengelolaan dana BOS masih sangat lemah dan belum memadai, hal ini disebabkan dalam penggunaan dana BOS tidak banyak melibatkan guru dan komite sekolah sebagai alat kontrol dalam perencanaan maupun dalam penggunaan dana. Mekanisme yang menjamin pengelolaan dilaksanakan secara transparan belum tersedia secara memadai, sehingga mengurangi tingkat akuntabilitas pengelolaan program BOS.

Bagaimana dengan implementasi program BOS di sekitar Salatiga? Hasil evaluasi Abdul Kadir Karding (2008) terhadap Pelaksanaan Program BOS Sekolah Menengah Pertama Negeri Di Kota Semarang menyimpulkan bahwa potensi BOS ternyata belum menjangkau semua siswa miskin/tidak mampu untuk memperoleh layanan pendidikan secara memadai; walaupun begitu, beberapa komponen yang semula dibebankan orang tua siswa melalui SPP menjadi berkurang, adanya peningkatan kuantitas dan kualitas sarana pendidikan, beban biaya sekolah menjadi lebih berkurang, dapat dirasakan masyarakat akan dapat mengurangi anak putus sekolah. Pada akhirnya dampak BOS ternyata dapat memperkuat kemampuan sekolah dalam memberikan materi pembelajaran dan kegiatan tambahan kepada siswa.

Hasil monev seperti tersebut, ternyata juga sejalan dengan hasil penelitian Dias Andris Susanto, Suwarno Widodo dan Rahmi Widyaningsih (2011) yang secara umum menunjukkan bahwa penggunaan dana BOS di SDN Kota Semarang sudah sesuai dengan petunjuk teknis pengelolaan, namun ketentuan mengenai komponen yang boleh dan tidak boleh didanai oleh BOS tidak bisa dilaksanakan secara konsisten oleh sekolah. Pihak sekolah mengalami kesulitan dalam LPJ; selanjutnya transparansi pengelolaan dana BOS kepada masyarakat masih rendah, orang tua kesulitan dalam mengetahui informasi BOS. Selanjutnya menarik juga untuk membandingkan dengan hasil penelitian La Ode Amaludin (2007) yang menyatakan bahwa di Kabupaten Buton, dalam pengambilan dan pemanfaatan dana BOS ditemukan adanya sekolah yang melakukan pemalsuan tanda tangan bendahara dan komite sekolah, bahkan terjadi pemanfaatan dana di luar peruntukannya dan pengalokasian anggaran secara fiktif; selain itu juga kurangnya pelibatan komite sekolah dan dewan guru dalam penggunaan dana BOS.

Gap yaitu perbandingan standard dengan capaian program seperti dikaji di atas, akan sangat berguna untuk menentukan adanya pertentangan. Penggunaan informasi pertentangan selalu mengarah pada satu dari empat pilihan:

1. Dilanjutkan ke tahap berikutnya bila tidak ada pertentangan. 
2. Jika terdapat pertentangan, kembali mengulang tahap yang ada setelah merubah standard program. 3. Jika tahap 2 tidak bisa terpenuhi, kemudian mendaur ulang kembali ke langkah 1- tahap definisi program, untuk menggambarkan kembali program tersebut, kemudian memulai evaluasi pertentangan lagi pada tahap 1.

4. Jika tahap 3 tidak bisa terpenuhi pilihannya adalah mengakhiri program.

Perlu disadari bahwa ada dan tidaknya kesenjangan yang terjadi seperti tersaji di atas, itu karena berbagai faktor, baik faktor internal sekolah yang bersangkutan maupun faktor eksternal; dan hal-hal itulah yang perlu mendapat perhatian dalam menentukan kemungkinan lebih lanjut. Kemungkinannya ada empat: a. menghentikan program, b. mengganti atau merevisi, c. meneruskan atau, d. memodifikasi misalnya salah satu adalah tujuannya. Berdasarkan temuan ini, yang paling pas adalah alternatif ke 4 yaitu memodifikasi Program BOS minimal pada aras implementasinya pada level sekolah dan supra strukturnya.

\section{PENUTUP}

Model monitoring dan evaluasi program menggunakan analisis kesenjangan ini menjadi salah satu alat ukur kualitas layanan/program dan kinerja penyedia layanan. Analisis yang bertumpu pada evaluasi diri dan observasi tentang gambaran nyata implementasi program BOS baik di aras sekolah sampai supra struktur yang kemudian dibandingkan dengan standard/norma teruji bahwa model ini cukup sederhana, memungkinkan untuk diterapkan dan digunakan secara luas karena mampu menghasilkan informasi yang lengkap,valid dan cepat dari berbagai dimensi program.

Berdasarkan analisis kesenjangan yang telah dilaksanakan tahun 2011/2012 diperoleh hasil monitoring dan evaluasi Implementasi BOS di Salatiga yang berupa simpulan berdasarkan standard, ternyata terdapat kesenjangan yang bervariasi: tinggi, sedang dan rendah baik menyangkut proses implementasi maupun hasil program.

Sesuai tujuan, dana BOS digunakan untuk mensubsidi seluruh siswa, sehingga dapat mengurangi iuran yang dibebankan kepada orang tua siswa; BOS diarahkan untuk membebaskan biaya pendidikan bagi siswa tidak mampu dan meringankan bagi siswa lain, mereka memperoleh layanan pendidikan dasar yang lebih bermutu sampai tamat SMP/MTs. Kendatipun kebijakan BOS ini berlaku secara nasional, pemerintah memberi jaminan/hak kepada sekolah untuk menolak BOS.

Hasil program BOS sesuai dengan tujuan yang seharusnya (kesenjangan rendah sampai cukup) mencakup: subsidi pemerintah (BOS) dapat menjadi akses untuk pengendalian pengelolaan dana pendidikan oleh manajemen sekolah, untuk menjamin penggunaan sumber daya finansial berlaku secara efisien, efektif, dan produktif. Dengan adanya BOS memberi peluang bagi sekolah untuk membelanjakan pada kegiatan-kegiatan (baru) yang sebelumnya tidak terpenuhi dari sumber iuran bulanan.

Terdapat kesenjangan yang tinggi dalam implementasi BOS, sehingga: ada keragukan apakah sekolah tetap dapat mempertahankan mutu pelayanan pendidikan apalagi masih harus menyelenggarakan sekolah gratis, apakah BOS digunakan secara transparan, dan para guru dilibatkan; dengan alokasi dana BOS yang diterima, sekolah belum dapat membebaskan seluruh biaya sekolah (hanya dapat membebaskan 40 - 70 persen dari biaya sekolah), sehingga masih harus melakukan penggalian dana dari sumber lain. 
Adanya kesenjangan yang tinggi dalam pencapaian hasil dari program BOS: terdapat sejumlah kebutuhan program sekolah yang strategis tetapi tidak dapat dibeayai oleh BOS (karena tidak sesuai aturan); Dana BOS belum mampu menanggung seluruh beban biaya siswa bersekolah (sekolah gratis); Sekalipun dana BOS dapat mengurangi beban orang tua untuk membayar pungutan lain di luar iuran bulanan, namun belum sepenuhnya dapat tercukupi.

Perlu disadari bahwa adanya kesenjangan yang terjadi itu karena berbagai faktor, baik faktor internal sekolah yang bersangkutan maupun faktor eksternal; dan hal-hal itulah yang perlu mendapat perhatian dalam menentukan kemungkinan lebih lanjut program BOS. Berdasarkan temuan ini, saran yang paling tepat adalah memodifikasi program BOS minimal pada aras implementasinya pada level sekolah dan dukungan dari supra struktur birokrasinya.

\section{DAFTAR PUSTAKA}

Abdul Kadir Karding. 2008. Evaluasi Pelaksanaan Program Bantuan Operasional Sekolah (BOS) Sekolah Menengah Pertama Negeri di Kota Semarang. Tesis. Program Pasca Sarjana Magister Administrasi Publik, Universitas Diponegoro Semarang.

Buku Peraturan Sekolah, 2003. Peraturan Sekolah. http://www.geocities.com/broway/alley/258/ 6/Buku Peraturan Sekolah.html.

Departemen Pendidikan Nasional. 2003. Undang-undang No. 20 Tahun 2003 tentang Sistem Pendidikan Nasional. Jakarta.

Dias Andris Susanto, Suwarno Widodo, dan Rahmi Widyaningsih, 2011. Akuntabilitas Pelaksanaan Bantuan Operasional Sekolah (BOS) di Sekolah Dasar Negeri Kota Semarang Tahun 2011. prosiding.ikippgrismg.ac.id/index.php/SHP/SHP/paper/view/11/10.

Erwantosi. 2010. Analisis Efektifitas, Akuntabilitas dan Transparansi Bantuan Operasional Sekolah Pada Sekolah Menengah Pertama di Kota Padang. Tesis. Program Pascasarjana Universitas Andalas.

La Ode Amaludin. 2007. Evaluasi Output Kebijakan Bantuan Operasional Sekolah (BOS) Pada Sekolah Dasar di Kabupaten Buton. SELAMI IPS. Edisi Nomor 22 Volume II Tahun XII Desember 2007.

Presiden RI. (2003). Undang-Undang Republik Indonesia No. 20 tahun 2003 Tentang Sistem Pendidikan Nasional. Jakarta: Depdiknas Dirjen Dikdasmen.

Suciptoardi. 2011. Evaluasi Program Malcolm Provus - DEM (Discrepancy Evaluation Model). http://suciptoardi.wordpress.com/2011/01/03/evaluasi-program-malcolm-provus-demdiscrepancy- evaluation-model//

Tilaar, H. A. R. 1970. Pembiayaan Pendidikan: Tanggung Jawab Masyarakat Dalam Penyelenggaraan dan Pembiayaan Pendidikan. Jakarta: Diktat Kuliah IKIP Jakarta.

Undang-undang No. 25 Tahun 2000 tentang Rencana Strategis Pembangunan Nasional 2000-2004.

Wibawa, Samodra dkk. 1994. Evaluasi Kebijakan Publik. Jakarta: PT. Raja Grafindo Persada. 